if one did escape, the team showed that the mutation can be undone by setting loose a second drive to 'overwrite' it. The results suggest that careful planning can reduce the risks while allowing gene-drive research to continue.

The concept of a gene drive is decades old, but the technique's application was hindered until the discovery a few years ago of a simple and versatile genome-editing system called CRISPR-Cas9. This system allows researchers to alter genomes with unprecedented precision and to engineer the fundamental components of a gene drive that transmit a copy of the edited sequence to nearly all offspring.

And because the CRISPR-Cas9 system is relatively easy to work with, the technology is now available to more laboratories than ever before. This is both a boon and a concern: it arms more great minds with a tool that could address serious public-health and environmental problems, but it also increases the chance that a laboratory might enter the field naive to the necessary safety precautions. This has understandably raised some safety concerns, and the US National Academies of Sciences, Engineering, and Medicine, for example, has convened a committee to evaluate uses of gene drives.

With this in mind, the Harvard researchers have been careful to announce their experimental plans before they carry them out. The experiments published this week were alluded to in previous publications outlining safety precautions that could be taken. The authors gathered feedback from the community, and used this to boost the safety of their own experiments. They were also careful to develop these safeguards before carrying out key laboratory experiments to explore the use of gene drives against Lyme disease, which is transmitted to humans through ticks, and schistosomiasis, a scourge carried by parasitic worms and most often found in Africa. All of these experiments have been discussed openly, before they were carried out.

Such openness is not standard practice. Scientific experiments are often subject to approval by institutional safety committees and
"Research involving gene drives must be handled with utmost care." funding agencies, but these discussions tend to be carried out behind closed doors. The public is sometimes surprised by what emerges. Witness the reaction earlier this year, when researchers announced that they had used CRISPR-Cas9 to edit the genomes of human embryos (see Nature 520, 593-595; 2015). About three years ago, a charged debate and research moratorium ensued when news broke that researchers intended to publish results showing how they had engineered the H5N1 influenza virus to make it more transmissible.

The Harvard gene-drive researchers have learnt from these debacles, and recognized the need to alert the wider community to their plans so that discussions can take place, concerns can be aired and suggestions offered from all corners before the work is done. Scientists should watch closely to see whether this approach could serve as a template for other teams that take on the challenge of working in controversial fields.

\section{Dope rules}

\section{Science is beside the point when an entrenched culture in a sport supports scoundrels.}

\section{$\mathrm{T}$} his month, the World Anti-Doping Agency (WADA) dropped a bombshell on the athletics world. In a scathing 335-page report issued on 9 November, the independent international agency alleged the existence of a far-reaching doping programme in Russian track and field that implicated government officials, sporting federations, coaches, athletes, scientists and doctors. As a result of Russia's widespread and institutionalized doping programme, the 2012 Olympic Games in London were effectively “sabotaged”, WADA concluded.

Russian athletes and coaches have subsequently been suspended from international track-and-field competitions by the International Association of Athletics Federations, whose laissez-faire policies over the years contributed to the scandal, according to WADA. There is a real possibility that Russian athletes will be banned from the 2016 Olympic Games in Rio de Janeiro, Brazil.

Science, some argue, can lead the way in achieving clean, or at least cleaner, sport. In the face of improved tests to detect doping, it will become harder for athletes to ingest performance-enhancing drugs without getting caught. Many say that the answer might lie with the biological passport, which looks for changes in blood chemistry from an individual's 'baseline' profile that may be indicative of doping. Suspect blood profiles have been used to nab cheats in professional cycling and endurance sports such as biathlons. And there have been claims from scientists at cycling's international federation, the UCI - itself subject to allegations of misconduct - that rampant blood doping became less common in the pro peloton (the elite professional cycling circuit) after biological passports were introduced.

There is no doubt that science can play a major part in anti-doping efforts. But this can only happen once a governance system is in place that has a genuine interest in clean sport. A series of doping scandals has shown that science is useless at catching cheats in a culture that doesn't really want to catch them - and in many cases is being used to help them.

Sophisticated biological passports are futile in a culture that encourages a leading anti-doping scientist to destroy blood and urine samples by the hundreds, while extorting money from athletes to do so. This is what WADA's report alleges of Grigory Rodchenkov, the former head of Russia's leading anti-doping lab. And the UCI looked the other way as Lance Armstrong doped his way to seven successive (and now rescinded) Tour de France victories, according to a report
"Sports that haven't been roiled by doping scandals may not be looking hard enough." issued this year by an independent commission appointed by the UCI.

Sports that haven't been roiled by doping scandals may not be looking hard enough. Financial incentives such as corporate sponsorships, broadcasting rights and merchandizing have the potential to discourage strong and independent anti-doping programmes. Just look at professional cycling, which has been forced to confront its massive doping problems. The sport's popularity has suffered, and spectacular performances such as those of Britain's Chris Froome now raise just as many suspicions as celebrations. Just imagine if, during an international tennis tournament, a 150-m.p.h. serve raised eyebrows rather than awe.

There will be calls for more and better anti-doping tests in the run-up to next year's summer Olympics in Rio and in other highprofile competitions. These are genuinely needed, because dopers tend to be a step ahead. Officials will hail their cutting-edge laboratories full of gleaming mass spectrometers and haemocytometers, and brag about how many urine and blood tests these can process each day never mind that savvy athletes tend to dope out of competition and in tiny doses that are nearly impossible to detect.

If past attitudes are anything to go by, we can expect officials to hide $\rightarrow$ NATURE.COM To comment online, click on Editorials at: go.nature.com/xhunqv behind science, while doing little to root out the fundamental problems that allow systemic sports doping to thrive. As Russia's doping scandal shows us, it is much easier to change a test tube than it is to change a culture. 